\title{
Nelson Rodrigues, da literatura para o cinema: uma análise sobre a adaptação audiovisual do romance $O$ Casamento
}

Fernanda Estiges Toledo ${ }^{\mathrm{i}}$

\begin{abstract}
RESUMO
O romance $O$ casamento (1966), de Nelson Rodrigues, conta as vinte e quatro horas que antecedem o casamento de Glorinha - filha caçula de Sabino. Este é surpreendido por seu amigo, Dr. Camarinha, com a notícia de que o noivo de Glorinha foi visto beijando outro homem na boca. A partir de então, descortinam-se os segredos mais recônditos da família de Sabino - que insistia em viver das aparências. Em 1975, Arnaldo Jabor decide fazer a adaptação dessa obra para o cinema. O presente estudo analisa em que medida Jabor realiza essa adaptação, buscando mostrar as estratégias empregadas por Jabor na tentativa de transpor a linguagem literária para o audiovisual. André Bazin, Robert Stam e Ismail Xavier são alguns dos teóricos que servirão de base para este estudo.
\end{abstract}

Palavras-chave: $O$ casamento; Literatura; Adaptação; Cinema.

\section{RESUMEN}

El romance $O$ casamento (1966), de Nelson Rodrigues, narra las veinticuatro horas que preceden el matrimonio de Glorinha - hija menor de Sabino. Este es sorprendido por su amigo, Dr. Camarinha, con la noticia de que el novio de Glorinha ha sido visto besando otro hombre en la boca. De este rato adelante, quedan-se aparentes los secretos más recónditos de la familia de Sabino - que intentaba vivir de las apariencias. En 1975, Arnaldo Jabor resuelve hacer la adaptación de este libro para el cine. El presente trabajo analiza hasta que punto Jabor realiza esa adaptación, buscando mostrar las estrategias usadas por Jabor en el intento de transponer el lenguaje literario para el audiovisual. André Bazin, Robert Stam e Ismail Xavier son algunos de los estudiosos tomados como referencia para este análisis.

Palabras clave: $O$ casamento; Literatura; Adaptación; cine.

\section{INTRODUÇÃO}

\footnotetext{
${ }^{i}$ Doutoranda em Literatura Brasileira na Universidade Federal do Rio de Janeiro (UFRJ). ORCID: https://orcid.org/0000-0003-1723-0892 | fernandaestiges@ gmail.com
} 
Nelson Rodrigues escreve o romance $O$ casamento em 1966, em plena ditadura militar. A narrativa - por trazer à tona traição, homossexualidade, amor incestuoso e estupro de vulnerável - escandaliza a sociedade. Um mês após seu lançamento, a obra é censurada pelo Ministro da Justiça do Governo Castello Branco: os exemplares são recolhidos e sua edição, distribuição e comercialização, proibidas em todo o território nacional. A terceira tiragem, já pronta para rodar, teve de ser cancelada. Segundo a Portaria de 12/10/1966, a obra atentava contra "a organização da família" (RODRIGUES, 2016, p. 264).

Entretanto, não foram todos que se chocaram com o seu enredo. Parte significativa do público a recebe positivamente e os números são prova disso: "oito mil exemplares [vendidos] nas primeiras duas semanas" (CASTRO, 1992, p. 350). O livro disputou a dianteira de vendas com Dona Flor e seus dois maridos, de Jorge Amado. Em 1975, Arnaldo Jabor faz a adaptação do romance para o cinema, assumindo a dupla função de roteirista e diretor.

A fim de tecer uma análise, mesmo que sucintamente, sobre as questões que envolvem os procedimentos intrínsecos em relação à adaptação, este trabalho se debruça sobre essa transposição da obra de Nelson Rodrigues para o cinema. O teórico de cinema Robert Stam (2020, p. 20), em seu artigo intitulado "Teoria e prática da adaptação: da fidelidade à intertextualidade", aponta que o "discurso elegíaco de perda" deve ser rechaçado. Sua observação nos convida à reflexão sobre a problemática da adaptação literária para o audiovisual, principalmente no que tange à questão da "fidelidade".

É provável que um leitor de $O$ casamento tenha percebido as diferenças não só no modo como as personagens são reconstituídas, mas também na própria organização do enredo no filme aqui em análise. Possivelmente dirá que o filme não "obedece" ao romance rodriguiano ${ }^{1}$. No entanto, a tentativa é demonstrar que os procedimentos implementados na adaptação fílmica recriam de forma análoga as personagens e as circunstâncias do romance de Nelson Rodrigues. Embora o julgamento por parte da crítica especializada ou por parte do público possa ser negativo, tentar-se-á demonstrar como a obra é reelaborada por Jabor na adaptação audiovisual.

\section{A ADAPTAÇÃO: UMA ADÚLTERA?}


Em seu livro Seis passeios pelos bosques da ficção, Umberto Eco (1994, p. 12) observa que o leitor, diante de um texto narrativo, precisa fazer escolhas a todo instante, sendo "obrigado" a decidir por qual caminho seguir tal qual em um bosque. A metáfora da qual Eco se utiliza para construir a ideia de que o texto narrativo oferece múltiplas direções de leitura é significativa quando pensamos o assunto adaptação. Isso porque o roteirista de um filme optou por uma interpretação plausível dentre outras opções das quais dispunha.

O romance $O$ casamento narra as 24 horas que antecedem o matrimônio de Glorinha, filha mais nova de Sabino. Este, casado há vinte e seis anos com Maria Eudóxia e pai de mais três filhas, é um homem bem-sucedido, diretor-presidente da Imobiliária Santa Teresinha. Na véspera do enlace, o ginecologista da família vê Teófilo - noivo de Glorinha - aos beijos com outro homem. A partir de então, a narrativa encaminha-se para "um carnaval de incestos e perversões às vésperas de um casamento" (CASTRO, 1992, p. 350), na qual os segredos mais íntimos - escondidos por uma sociedade travestida de família de bem - são revelados. A miserabilidade humana e as obsessões das personagens são expostas.

De acordo com Ângela Maria Dias (2013, p. 91), a obra "apresenta uma estrutura fortemente dramática, toda ela assentada nos dois elementos cruciais à teatralidade: a ação e o diálogo". Ora, Nelson Rodrigues inicia sua carreira literária como dramaturgo. Não surpreende, pois, verificar sua veia dramatúrgica percorrendo o romance em questão. Conforme sinalizado por Dias, a estrutura narrativa de $O$ casamento já fornece elementos cruciais para a sua encenação. O trabalho realizado por Jabor, nesse sentido, será o de selecionar a abordagem que se quer realizar.

Contudo, não podemos perder o foco de que Jabor é (mais) um leitor e, segundo Eco (1994, p. 7), “numa história sempre há um leitor, e esse leitor é um ingrediente fundamental não só do processo de contar uma história, como também da própria história". Sendo assim, retornando à metáfora do bosque, Jabor faz uma escolha ao imprimir "um ritmo frenético e apocalíptico" (DIAS, 2013, p. 91) ao filme homônimo à obra de Nelson Rodrigues. Mas o que dizer das partes suprimidas ou acrescentadas? Estaria sendo fidedigno ao romance?

Essa cogitação de que a adaptação deve corresponder à obra na qual se baseia remete à noção de fidelidade. Comportar-se-ia, pois, como uma adúltera, uma vez que 
não é fiel ao romance nelsonrodriguiano? O crítico e teórico de cinema André Bazin (2014, p. 114), em seu ensaio "Por um cinema impuro - defesa da adaptação", discorre sobre as implicações das adaptações que a sétima arte realiza dos textos literários. Para ele, o que o cineasta faz é "transcrever para a tela, numa quase identidade, uma obra cuja transcendência ele reconhece a priori". A partir de suas considerações, percebe-se que a noção de fidelidade é rechaçada.

Isso acontece porque o cineasta não quer apenas transpor literalmente o que leu, seu intuito é o de recriar considerando a linguagem pertinente ao universo cinematográfico. Ou seja, as adaptações feitas a partir da literatura não serão uma cópia fiel do enredo. Logo, o trabalho realizado pelo cineasta não deve ser pré-julgado por escolhas que findem por modificar a ordem do enredo ou a supressão de determinada cena, por exemplo. Perpassar pelo processo estético intrínseco ao audiovisual é imprescindível para despojar-se dos preconceitos relativos à adaptação.

Nesse sentido, saber que a narrativa cinematográfica se firma numa constante tensão entre diegese e mimese é primordial a fim de compreender a sua natureza narrativo-representativa, visto que narra e mostra concomitantemente. Sendo assim,

[...] contar uma história no cinema, portanto, é fazê-lo através de códigos representacionais (qualidade icônica da imagem fotográfica, encenações de atores, estrutura cênica) e de códigos narrativos (mise-en-scène, narrador fílmico, flexibilidade espaço-temporal da câmera). (SILVA, 2007, p. 35)

Jabor, portanto, busca estratégias que deem conta de representar o código linguístico. Para isso, músicas de fundo, vestimentas, cenários, tomadas da câmera, expressões faciais e tom de voz dos atores, por exemplo, serão cuidadosamente selecionados a fim de transmitir para quem vê a interpretação que o roteirista teve.

De pronto, o filme já desperta a curiosidade por sua abertura: enquanto toca a marcha nupcial - canção extremamente clichê nos casamentos -, imagens reais de uma enchente vão sendo mostradas. $\mathrm{O}$ espectador que por ventura não tenha lido o romance talvez não compreenda o que aquela enchente anuncia: a derrocada de uma família pequeno-burguesa. E, por extensão, a derrocada do casamento -, para o crítico literário Terry Eagleton (2013, p. 251), a "mais característica das instituições burguesas". As imagens da enchente se contrapõem à marcha nupcial, já que esta remete à ideia de "pompa e circunstância" enquanto aquelas mostram a miséria humana. 
No entanto, se num primeiro momento o espectador não é capaz de realizar essas inferências, certamente as fará ao final do filme, depois que toda a encenação tiver se encerrado. Ele irá atar - de modo análogo ao que faz a personagem de Dom Casmurro "as duas pontas da vida" (ASSIS, 1997, p. 14), nesse caso, do ponto de vista cinematográfico, as duas pontas do espetáculo, cujo fim explica o início, ocorrendo o fechamento de um ciclo. Sendo o próprio casamento também a simbologia de um ciclo, uma vez que representa a finitude de uma vida e o começo de outra. Como é possível certificar, Jabor empreende estratégias inerentes ao audiovisual para reproduzir o conteúdo das páginas de Nelson Rodrigues.

Outra imagem que abre o filme é a de desabamentos, dos quais bombeiros tentam resgatar as pessoas. Numa clara alusão ao desmoronamento que há dentro do enredo rodriguiano: o desmantelamento das convenções sociais e de todo o fingimento no qual a família de Sabino estava assentada. A marcha nupcial segue tocando paralelamente até ser interrompida pelo barulho de britadeiras operadas por alguns homens. Em meio às britadeiras, surge Sabino gritando; a cena corta abruptamente para um flashback: é a lembrança de seu pai agonizando quando ele era ainda uma criança.

O som das britadeiras é o recurso de que Jabor se utiliza para transpor para a tela a mente atormentada de Sabino pela morte de seu pai: "O pai morrera defecando. Não conseguiria esquecer, nunca, as fezes da agonia" (RODRIGUES, 2016, p. 13). Nesse início do longa-metragem, Jabor constrói metáforas a partir do barulho promovido pelas britadeiras na tentativa de dar conta da transposição de assuntos que permeiam a narrativa. Tais metáforas, portanto, acolhem o universo gráfico do romance. O flashback é interrompido, e Sabino aparece em sua cama acordando agitado sob o som das britadeiras que cessa. Levanta-se e, diante do espelho, profere uma das falas mais icônicas do livro: “- Homem de bem.” (RODRIGUES, 2016, p. 7).

Os efeitos provocados por essa abertura dialogam com a ideia da adaptação literária para o audiovisual, visto que a tela expõe de modo enxuto as principais questões que norteiam o romance, não sendo possível a transposição literal de cena a cena, de diálogo a diálogo do livro para o filme. Jabor opta por realizar um recorte dos conteúdos centrais da narrativa, como é o caso do amor incestuoso de Sabino por Glorinha - tanto que o episódio após a fala dele em frente ao espelho é justamente ele no quarto da filha observando-a dormindo seminua. Na sequência, surge Sabino, caminhando em direção à 
câmera, contemplando um vestido de noiva enquanto o volume da Sinfonia n 7 (Op. 92), de Beethoven, aumenta até ganhar toda a cena. Nesse momento, há uma referência visual mais explícita ao evento das bodas - situação da qual toda narrativa gira em torno, visto que, segundo Sabino, “o casamento já é indissolúvel na véspera” (RODRIGUES, 2016, p. 26). As estratégias empregadas por Jabor chamam-nos atenção por revelar o caráter "impuro" do cinema. Isto é, há uma série de influências de outros meios de expressão, conforme sinaliza João Batista de Brito:

o cinema é, por natureza, uma arte heterogênea que soma características básicas das outras modalidades de arte existentes, um autêntico compósito que sintetiza em si mesmo, entre outras coisas: a plasticidade da pintura, o movimento e o ritmo da música e da dança, a (pseudo) tridimensionalidade da escultura e arquitetura, a dramaticidade do teatro, e a narratividade da literatura. (BRITO, 1995, p. 12)

Toda essa diversidade de que é composto o cinema possibilita entrever a sua demanda na tentativa de dar conta do que está escrito nas páginas do romance. As interferências que sofreu - e ainda sofre - derrubam qualquer ideia de "pureza". Robert Stam (2006, p. 23), em seu artigo “Teoria e prática da adaptação: da fidelidade à intertextualidade", corrobora o ponto de vista de Brito, pois, para ele, “a adaptação [...] pode ser vista como uma orquestração de discursos, talentos e trajetos, uma construção 'híbrida', mesclando mídia e discursos. [...] A originalidade completa não é possível nem desejável". Ou seja, o pensamento de que o cinema seria uma "arte pura" é novamente afastada.

Portanto, constata-se que o questionamento de que a adaptação soaria como uma adúltera não se confirma. Apesar de literatura e cinema contemplarem signos e códigos tão distintos, Jabor dá conta de expressar o discurso literário rodriguiano. Cabe destacar que o próprio Nelson por muitas vezes bebeu na fonte do cinema para escrever suas peças. Averígua-se, pois, que há uma via de mão dupla que enriquece a produção tanto literária quanto cinematográfica. Sábato Magaldi ressalta que

\footnotetext{
Nelson, estimulado pela linguagem do cinema, retirou o teatro das quatro paredes rígidas do palco. Desrespeitou a composição tradicional da peça, que observava a apresentação, o desenvolvimento e o desfecho do tema, em marcha cronológica. Numa fase em que a psicanálise remontava à infância para decifrar o adulto, a narrativa não poderia concentrar-se apenas no presente, sob pena de perder as motivações profundas. (Magaldi, 2010, p. 45-46)
} 
Observa-se que Nelson transita por outras searas ao produzir seus textos sem haver qualquer tipo de questionamento quanto à sua originalidade. Ao contrário, justamente por inserir em seu teatro - não apenas, mas também - técnicas próprias do cinema, inaugura a modernidade em nossa dramaturgia. Tal perspectiva corrobora a concepção de que a troca entre essas duas modalidades de discurso é um tanto quanto frutífera. Sendo assim, o pensamento de "arte pura" dentro da ótica cinematográfica configura uma falácia. $\mathrm{O}$ fato de Jabor não seguir linearmente o enredo não exclui os acontecimentos que nele estão presentes; longe disso, a tela exibe a interpretação do roteirista/ diretor convertendo a linguagem verbal em imagens.

\section{A "INTERPRETAÇÃO LIVRE" DO CINEASTA NA CONSTRUÇÃO DA ADAPTAÇÃO}

No que tange à perspectiva da adaptação, o teórico Ismail Xavier (2003, p. 61) aponta a "interpretação livre" como uma maneira de enxergar a seleção feita pelo roteirista. No caso de Jabor, as modificações implementadas por ele conferem um tom operístico ao filme. Tal característica é uma escolha completamente livre - empreendida a partir de seu ponto de vista. Sendo Nelson Rodrigues um dramaturgo nato, a mescla de gêneros no romance é inegável - como já apontado na presente análise; em diversos momentos, a passagem do narrador funciona como uma rubrica: "Estendia-lhe as duas mãos enormes" (RODRIGUES, 2016, p. 48). Além disso, os diálogos na obra literária aproximam-se tanto de uma peça teatral que a trajetória escolhida por Jabor é justamente a de conduzir o filme conferindo-lhe um caráter de teatralidade.

A opção feita por Jabor parece ser a do caminho contrário, ou seja, agora é a linguagem cinematográfica que apropriar-se-á do mundo do teatro. De acordo com Ismail Xavier, houve uma mudança no modo de se ver o trabalho desenvolvido pelo cineasta. Ele destaca que "a interação entre as mídias tornou mais difícil recusar o direito do cineasta à interpretação livre do romance ou peça de teatro" (XAVIER, 2003, p. 61). Desse modo, percebe-se que há uma liberdade maior por parte de Jabor quanto ao recorte empreendido, propondo uma outra maneira de compreender algumas passagens e alterando a hierarquia de certas personagens. Além disso, Jabor lança luz sobre a mudança 
no modo como a adaptação deve ser vista, respeitando as especificidades das respectivas linguagens:

\begin{abstract}
A fidelidade ao original deixa de ser o critério maior de juízo crítico, valendo mais a apreciação do filme como nova experiência que deve ter sua forma, e os sentidos nela implicados, julgados em seu próprio direito. Afinal, livro e filme estão distanciados no tempo; escritor e cineasta não têm exatamente a mesma sensibilidade e perspectiva, sendo, portanto, de esperar que a adaptação dialogue não só com o texto de origem, mas [também] com o seu próprio contexto, inclusive atualizando a pauta do livro, mesmo quando o objetivo é a identificação com os valores nele expressos. (XAVIER, 2003, p. 61-62, ênfase acrescentada)
\end{abstract}

Esse novo olhar lançado sobre a adaptação diz muito sobre a feitura do audiovisual, uma vez que não há nenhuma obrigação em seguir de forma rígida a produção literária, sendo esta passível de uma "atualização" por parte da perspectiva do cineasta. Ademais, a distância temporal de nove anos entre livro e filme possibilita, nesse caso, que Jabor tenha uma consciência sobre o objeto no qual se concentra. Considerar esse diálogo respeitando que não se trata de uma reprodução exata - o que seria impossível conforme já exposto aqui - é uma vereda quando se discute essa questão da adaptação.

Tânia Pellegrini (2003, p. 15), em seu artigo "Narrativa verbal e narrativa visual: possíveis aproximações", faz referência ao conceito de "peso visual" - que é justamente o apelo visual que a imagem tem. Logo, ao transpor para o cinema a narrativa nelsonrodriguiana, o espectador desfrutará de "vestimenta, caracterização e comportamento das personagens, [diferentemente] de um contexto verbal" (PELLEGRINI, 2003, p. 15). Dessa forma, conseguimos captar a época em que se passa a narrativa ou, ainda, "se se trata de drama ou comédia" apenas pelo "conjunto de significados visuais" (PELLEGRINI, 2003, p. 15). Os gestos e expressões faciais auxiliam de maneira contundente na compreensão da trama. Evidentemente, os mecanismos aos quais o cineasta necessita recorrer são distintos daqueles implementados no livro - conforme já apontado. Sendo assim, ao darmos prosseguimento à análise da “interpretação livre" praticada por Jabor, chegamos à conclusão de que ele faz um verdadeiro recorte no romance.

No filme, nem todos os elementos dispostos na narrativa original aparecem e aqueles que são apresentados ao espectador sofrem alterações em relação à ordem que 
lhes deu Nelson Rodrigues em seu romance homônimo. Além disso, o destaque que ganham na adaptação cinematográfica também é bastante distinto da composição literária. É o que se verifica, por exemplo, com a personagem de Antônio Carlos - filho do Dr. Camarinha - que ganha um papel de maior notoriedade por aparecer em várias ocasiões, dando a impressão, inclusive, de que ele é um dos protagonistas, quando, no original, aparece poucas vezes apenas nas lembranças de seu pai e de Glorinha através de flashbacks.

O recurso do flashback nas peças de Nelson - e no romance em questão - é bastante recorrente e merece atenção. O que acontece com essa adaptação para as telas de sétima arte é um alongamento dessas recordações, o que resulta em um domínio do que está sendo lembrado, “[...] a força da cena presente no palco (ou na tela) diante dos olhos adquire uma dimensão própria e embaralha nossa perspectiva em face da experiência das personagens" (XAVIER, 2003, p. 81). Isso é exatamente o que se verifica na adaptação aqui discutida. Logo, quem assiste ao longa-metragem tem a impressão de que essas passagens duraram mais tempo na narrativa.

Nesse sentido, Ismail Xavier (2003, p. 67) ainda aponta que, embora seja possível identificar com precisão o que foi mantido e o que foi suprimido, “[...] dificilmente haverá consenso quanto ao sentido de tais permanências e transformações". Ao considerar a colocação do teórico, há de se pensar nos motivos pelos quais não aparecerem o estupro de vulnerável cometido por Sabino e o ménage à trois entre Antônio Carlos, Glorinha e Maria Inês - amiga de Glorinha. Provavelmente, a opção por deixar essas passagens de fora justifica-se pela quebra do "[...] decoro da representação (em geral, no caso da representação do sexo ou da violência)" (XAVIER, 2003, p. 74) que determinado episódio poderia causar.

As cenas que Jabor decidiu não recriar são justamente as mais fortes, que poderiam chocar - ainda mais - o público de cinema; como se já não bastasse o amor incestuoso de Sabino por Glorinha mantido na adaptação. De modo geral, mantém-se no filme o que é mais aceitável; o que "[...] está sujeito aos tabus de caráter moral e que afeta o corpo" (XAVIER, 2003, p. 74) é suprimido. No cinema, “[...] os corpos estão efetivamente à vista na encenação da violência ou da sexualidade" (XAVIER, 2003, p. 74), ou seja, ficam mais expostos, diferentemente do texto escrito em que as circunstâncias são recriadas subjetivamente na mente do leitor. 
Embora atualmente o cinema tenha exposto cada vez mais as cenas de nudez e violência, não podemos desconsiderar dois momentos vivenciados na ocasião em que surge o filme: primeiramente, o contexto político da ditadura militar - que poderia censurar o filme caso muitos conteúdos imorais aparecessem; em segundo lugar, o distanciamento da chanchada - que consistia na exploração do erotismo. Ambas considerações também são relevantes para se compreender os cortes ocorridos no texto original, uma vez que a conjuntura histórica interfere na produção cultural do país.

Ao considerarmos, ainda, o contexto político no qual a adaptação foi produzida, conseguimos perceber a crítica a uma família burguesa que vive sua deterioração, mas que insiste em manter as convenções sociais. Tanto que Sabino, repetidas vezes, profere: “-O importante é o casamento!” (RODRIGUES, 2016, p. 261). Tal crítica já está contida originalmente no romance, contudo, Jabor faz questão de enfatizá-la. De maneira análoga a Oswald de Andrade - que utilizou uma série de recursos estéticos em favor da representação da visão política que tinha -, Jabor emprega certos procedimentos em sua produção cinematográfica a fim de criticar a sociedade burguesa e seus falsos moralismos. As cenas hiperbólicas e a estrutura elíptica constroem com bastante veemência a ideia de derrocada da família burguesa brasileira. Isso se deve à veia cinemanovista do roteirista e diretor. Vale lembrar que o Cinema Novo, ao voltar-se para o Brasil, não queria descrever “[...] costumes locais, mas sim ter da sociedade brasileira uma visão crítica, analisar suas contradições numa perspectiva sociológica” (BERNARDET, 2009, p. 107). Ou seja, os cinemanovistas, ao realizarem suas adaptações, queriam não apenas retratar o cenário brasileiro, mas também contestá-lo.

Em relação à estrutura narrativa, cabe ainda destacar a seleção do foco narrativo ou ponto de vista, uma vez que essa escolha influirá diretamente na condução da narrativa. Isto é, o que querem que o leitor tenha conhecimento e de que forma esse conhecimento será transmitido.

A montagem cinematográfica de $O$ casamento mantém o foco narrativo do romance em terceira pessoa. No entanto, enquanto a obra literária nos permite saber o que se passa no pensamento das personagens, já que emprega um narrador-onisciente, o mesmo não ocorre ao longo do filme. Acompanhamos a câmera e os diálogos entre as personagens sem saber o que pensam. Sabemos o mesmo que as personagens na medida 
em que os fatos se desenrolam. O diretor opta por deixar "[...] a história correr como se fosse observada de uma janela transparente" (XAVIER, 2003, p. 69).

Essa característica de colocar o espectador na frente da cena, supostamente, sem nenhum tipo de mediação, foi denominada por Ismail Xavier (2003, p. 73) de "modo dramático". A escolha por tal modo talvez esteja relacionada à "[...] identificação 'direta' com o mundo ficcional" (XAVIER, 2003, p. 70) que esse recurso proporciona. Sendo assim, o espectador é colocado no papel de uma testemunha ocular, ou seja, ele está vendo e sabendo tudo o que acontece com as personagens, e os artifícios usados para essa finalidade fazem com que ele realmente acredite nisso. Ao fazer essa análise, percebe-se que o propósito de Jabor ao optar por esse modo e, não, pelo "modo épico" (XAVIER, 2003, p.73) - cuja representação ocorre por intermédio do narrador - é o de aproximar o espectador do que está sendo contado, sem que este tenha a nítida sensação de estar diante da ficção.

A maneira como o contar se apresenta no romance rodriguiano funciona perfeitamente, desempenhando a sua função de prender o leitor e aguçar a curiosidade dele, levando-o a devorar a narrativa até seu desfecho. O ritmo empreendido por Nelson é veloz, com muitos diálogos e uma dose de suspense. O narrador não revela tudo, o leitor necessita fazer suposições a todo instante a fim de suplementar as brechas do enredo. $\mathrm{O}$ amor incestuoso de Sabino por sua filha caçula, por exemplo, não transparece explicitamente, “[...] em $O$ casamento os sentimentos mais recônditos de Sabino em relação à Glorinha são revelados aos poucos, criando uma atmosfera de incertezas ao longo da narrativa" (TOLEDO, 2019, p. 40).

Nesse sentido, Jabor busca empreender um ritmo que mantenha o suspense da narrativa original; por isso cria imagens que potencializem um "efeito de choque" (XAVIER, 2003, p. 76). Embora possa soar exagerado para muitos, cumpre a tarefa a que se propõe: a de trazer às telas uma ótica a partir de uma obra literária. Nota-se que Jabor opta pelo emprego de um tom operístico que é verificado nas falas, nos gestos e nas expressões faciais - recurso possível apenas por se tratar de audiovisual.

\section{A TRILHA SONORA NA CONSTRUÇÃo dA CONOTAÇÃo OPERÍSTICA}


A trilha sonora tem papel fundamental na construção da adaptação feita por Jabor. É ela, na realidade, que confere grande carga teatral ao filme, além de contribuir de maneira decisiva para esse tom operístico. Além da marcha nupcial na abertura do filme - já apontada anteriormente neste estudo -, há duas cenas especificamente que se faz necessário abordar a fim de trazer luz a essa questão. Há um momento no filme -assim como no livro - em que Glorinha pede a Dr. Camarinha que a examine com o objetivo de que ele comprove sua virgindade:

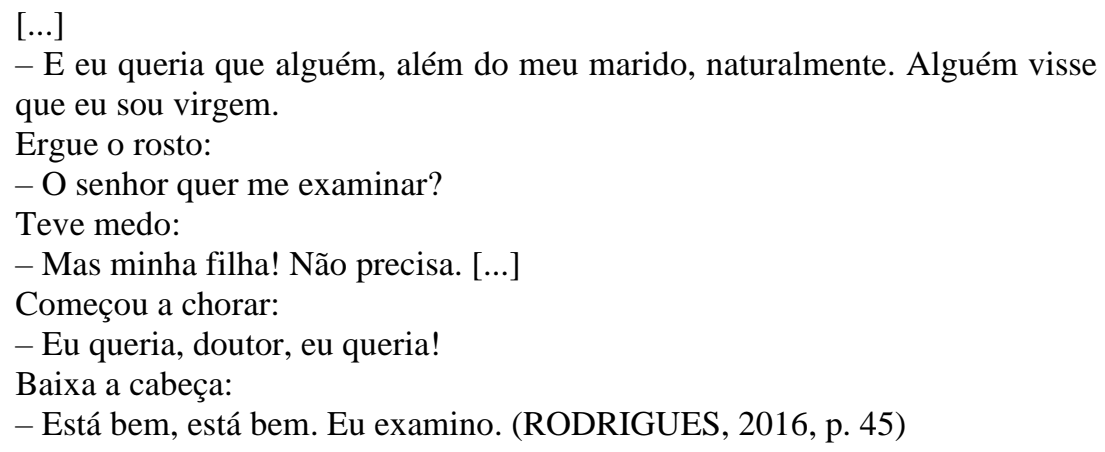

Esse diálogo, contudo, não acontece dessa forma na adaptação. No longa, Glorinha comporta-se de um jeito despudorado, já que o choro presente no diálogo acima - um tanto quanto ambíguo, uma vez que confere, por um lado, um quê de inocência e, por outro, de dissimulação - inexiste no filme. Além disso, a personagem fica completamente nua, enquanto que originalmente retira apenas a calcinha. A liberdade interpretativa desfrutada por Jabor possibilita não só a alteração na cena, como também a seleção da música de fundo - e é justamente nesse ponto que incide nossa análise. Nesse instante, toca a introdução ao canto gregoriano - muito utilizada no ritual da liturgia católica romana. $\mathrm{O}$ efeito provocado remete diretamente à ideia de sagrado e profano, tão peculiar nas tramas nelsonrodriguianas. Conforme aponta Victor Hugo Adler Pereira,

\footnotetext{
“[...] Glorinha, de $O$ casamento, repete um dos modelos de personagem feminina na obra de Nelson Rodrigues, norteado pela ambiguidade ou reversibilidade entre a 'pureza/ impureza': considerada pelo pai como uma esperança na possiblidade de pureza; tem, no entanto, uma vida sexual bastante acidentada". (PEREIRA, 1999, p. 145)
}

A personagem de Glorinha trará essa dubiedade ao longo de toda narrativa, inclusive, quanto à correspondência ou não ao amor incestuoso de seu pai. Nesse 
momento da trama, esse comportamento dúbio fica ainda mais evidente. Ao final da conversa, Glorinha interroga o médico:

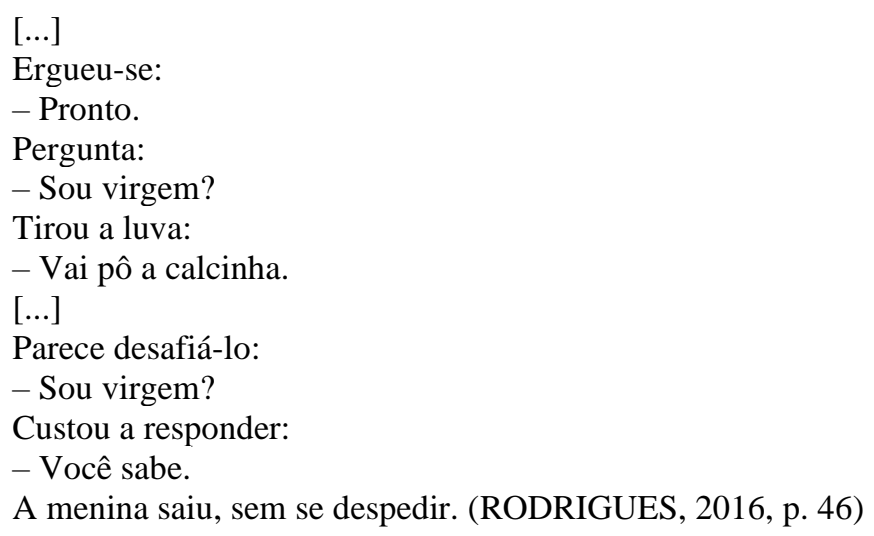

O leitor envolvido com o enredo pode não ter certeza, mas desconfia que Glorinha já havia mantido relações íntimas - vale destacar que o ménage à trois do qual ela participa ainda não havia sido explicitado na narrativa. $\mathrm{Na}$ adaptação, entretanto, o médico a questiona a respeito de sua insistência para verificar sua virgindade, já que ela sabia que não era mais virgem. Ou seja, seu defloramento fica evidente, não há dúvidas. Nessa direção, pode-se dizer que a canção ao fundo conduz a interpretação que o diretor quer que o espectador tenha: a de que a pureza e o comportamento de boa moça de Glorinha são apenas aparentes.

Sendo assim, a ambiguidade a que se refere Victor Hugo Adler Pereira, existente na obra literária - personificada através do choro -, faz-se presente no longa através da música que toca nesse instante. Em síntese, é como se o choro de Glorinha - que lhe outorga um quê de inocência e desfaçatez - tivesse sido substituído pelo canto gregoriano. Jabor encontra uma outra forma de representar a sua personalidade. Apesar da manutenção da ambiguidade, chamam-nos atenção - mais uma vez - os recursos dos quais o diretor lança mão a fim de manter a caracterização ambivalente da personagem em questão.

A outra cena na qual a trilha sonora produz forte impacto é a do ato sexual entre Noêmia - secretária de Sabino - e Xavier - amante de Noêmia. A música escolhida é "La mamma morta", tendo como intérprete a soprano Maria Callas, que ficou mundialmente conhecida em meados do século XX. Na medida em que a canção avança, os amantes envolvidos na cama parecem um só. O close no rosto de Noêmia revela uma mistura de 
dor e prazer. As expressões faciais são todas muito exageradas: os olhos arregalados, as sobrancelhas erguidas, os braços estendidos e o lençol mordido com força. Tudo milimetricamente feito de modo a conferir ainda mais dramaticidade à cena, o que remonta à teatralidade presente no filme.

Além disso, há um dado relevante para a análise aqui em questão e que por isso merece um olhar mais atento: o conteúdo de "La mamma morta", em certa medida, aproxima-se à vida miserável de Noêmia. Mesmo que não se conheça a tradução da canção, é possível inferir que se trata de um teor triste, que remete à dor e ao sofrimento. A ópera a qual "La mamma morta" pertence é baseada na vida de Andrea Chénier (1762 - 1794), que foi um poeta decapitado durante a Revolução Francesa (1789). A composição é de Umberto Giordano (1867 - 1948):

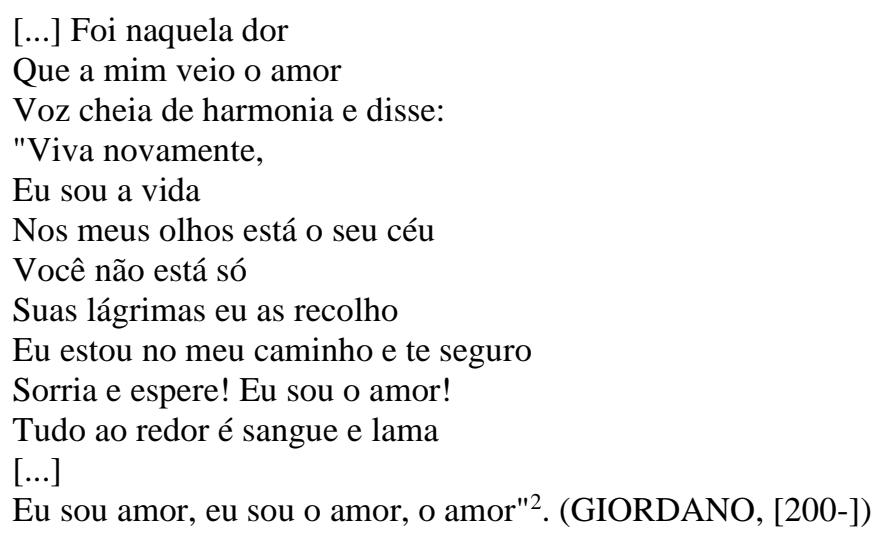

Ao remetermo-nos à vida de Noêmia, verificamos a semelhança com sua realidade sofrida e triste. Ela, que mal tinha dinheiro para comer e pagar o quarto onde vivia, ao conhecer Xavier - "o amor" -, sente-se menos solitária e começa a ter esperança de uma vida feliz. Noêmia acredita que ele pode retirá-la da lama em que se encontra.

Embora o conhecimento de todas essas informações referentes à canção não seja pré-requisito a fim de se compreender a narrativa em curso, após a elucidação desses aspectos, é possível captar nuances que antes poderiam passar despercebidamente. Isto é, o espectador mais atento conectará a vida da personagem à história narrada por sua trilha sonora. Logo, percebe-se que tal escolha não é apenas coincidência. Ademais, o fato de se ter uma ópera como música de fundo para uma cena como a que foi descrita reforça o tom operístico no longa-metragem. Mais uma vez, a seleção por parte do diretor interfere na interpretação de quem assiste ao longa. Isso porque os diálogos inflamados dão um 
tom de exagero ao filme. A trilha sonora aqui mencionada e os close-up são responsáveis, em grande medida, pela condução interpretativa do público, dando uma conotação operística. Dessa forma, o filme configura-se de maneira muito mais hiperbólica do que as palavras permitem entrever.

\section{CONSIDERAÇÕES FINAIS}

Apesar das diferenças empreendidas na adaptação do romance nelsonrodriguiano, é compreensível que elas ocorram, uma vez que tratamos de mídias distintas. Logo, o processo da recepção abordado aqui também ocorrerá de outro jeito. Até mesmo porque, vale ressaltar, só fará esse tipo de comparação, no que tange às lacunas deixadas pelo romance - e que inexistem no filme -, quem leu a obra. Não quer dizer, contudo, que outras brechas não possam ser enxergadas pelo espectador e que, desse modo, outros questionamentos lhe surjam.

Enquanto Nelson Rodrigues inaugura o teatro moderno brasileiro, o Cinema Novo inaugura o cinema moderno no Brasil. Ambos, no ímpeto de abordar a sociedade brasileira, promovem verdadeiras inovações. Sendo assim, contribuem para a renovação no cenário cultural do país. Jabor - valendo-se do processo intertextual apontado por Stam - traz um novo olhar sobre a narrativa rodriguiana. Deve-se, pois, pensar nos ganhos que a adaptação possibilitou e não lamentar as possíveis "perdas". Esta última ideia é condenada por Stam justamente por trazer a falsa perspectiva de que a produção literária é superior à cinematográfica.

Por fim, a ideia de "impureza" levantada por Bazin, e trazida à tona no início deste artigo, configura-se como muito positiva, já que o diálogo entre cinema e literatura se apresenta de maneira extremamente fecunda. Ainda que a adaptação do romance $O$ casamento feita por Jabor guarde dissonâncias, o fato de ele se apropriar da literatura com a finalidade de transpor para a linguagem cinematográfica demonstra a manutenção dessa interlocução tão necessária às artes. Ademais, é sempre produtivo ver os diálogos nelsonrodriguianos - recurso aperfeiçoado pelo escritor na sua labuta de dramaturgo - em ação, uma vez que encontramos neles a captação da vida como ela é.

\section{Referências}


ASSIS, Machado. Dom Casmurro. São Paulo: Editora Ática, 1997.

BAZIN, André. "Por um cinema impuro". In: O que é o cinema? Tradução de Eloisa Araújo Ribeiro. São Paulo: Cosac Naify, 2014.

BERNARDET, Jean-Claude. Cinema brasileiro: propostas para uma história. São Paulo: Companhia das Letras, 2009.

BRITO, João Batista de. Literatura, cinema, adaptação. Graphos. João Pessoa, v. 1, n.2, 1995. p. 9-28.

CASTRO, Ruy. O anjo pornográfico: a vida de Nelson Rodrigues. São Paulo: Companhia das Letras, 1992.

DIAS, ÂNGELA MARIA. A forma da emoção. Rio de Janeiro: 7Letras, 2013.

EAGLETON, Terry. A ideia do trágico. Tradução de Alzira Allegro. São Paulo: Editora UNESP, 2013.

ECO, Umberto. Seis passeios pelos bosques da ficção. São Paulo: Companhia das Letras, 1994.

GIORDANO, Umberto. La mamma morta. [200-]. Letras. Disponível em: www.letras.mus.br/maria-callas/225224/traducao.html. Acesso em: 16abr.2021.

MAGALDI, Sábato. Nelson Rodrigues: dramaturgia e encenações. São Paulo: Perspectiva, 2010.

O CASAMENTO. Direção de Arnaldo Jabor. BRA: Paulo Porto, Eduardo Mascarenhas e Sidnei Cavalcanti; Ipanema filmes, 1975. 1 DVD (96 min).

PELLEGRINI, Tânia. "Narrativa verbal e narrativa visual: possíveis aproximações". In: ; JOHNSON, Randal; XAVIER, Ismail; GUIMARÃES, Hélio de Seixas; AGUIAR, Flávio Wolf de. Literatura, cinema e televisão. São Paulo: Senac, 2003.

PEREIRA, Victor Hugo Adler. Nelson Rodrigues e a obs-cena contemporânea. Rio de Janeiro: EdUERJ, 1999.

RODRIGUES, Nelson. O casamento. Rio de Janeiro: Nova Fronteira, 2016.

SILVA, Marcel Vieira Barreto. Cinema e literatura dramática: alguns pontos de vista sobre as linguagens teatral e cinematográfica. Graphos. João Pessoa, v. 9, n. 1, p. 35-43, 2007.

STAM, Robert. Teoria e prática da adaptação: da fidelidade à intertextualidade. Ilha do Desterro. 2006. 
https://periodicos.ufsc.br/index.php/desterro/article/view/2175-8026.2006n51p19.

Acesso em: 18 mar. 2020.

TOLEDO, Fernanda Estiges. O casamento: o percurso do Nelson Rodrigues romancista. Dissertação (Mestrado em Letras). Faculdade de Letras, Universidade Federal do Rio de Janeiro, Rio de Janeiro, 2019.

XAVIER, Ismail. "Do texto ao filme: a trama, a cena e a construção do olhar no cinema". In: PELLEGRINI, Tânia; JOHNSON, Randal; XAVIER, Ismail; GUIMARÃES, Hélio de Seixas; AGUIAR, Flávio Wolf de. Literatura, cinema e televisão. São Paulo: Senac, 2003.

Recebido em: 04/06/2021

Aceito em: 21/07/2021

\footnotetext{
${ }^{1}$ Sigo aqui a forma "rodriguiana" e, não, "rodrigueana" para empregá-la conforme Sábato Magaldi em Nelson Rodrigues: dramaturgia e encenações. São Paulo: Perspectiva, 2010.

${ }^{2}$ Traduzido do original: “[...] Fu in quel dolore/ Che a me venne l'amor/ Voce piena d'armonia e dice:/ 'Vivi ancora/ Io son la vita/ $\mathrm{Ne}$ ' miei occhi e il tuo cielo/ Tu non sei sola/ Le lacrime tue io le raccolgo/ Io sto sul mio cammino e ti sorreggo/ Sorridi e spera! Io son l'amore!/ Tutto intorno è sangue e fango/ [...]/ Io son l'amore, io son l'amor, l'amor". A tradução aqui apresentada foi feita pela autora deste artigo.
} 